\title{
A DYNAMIC DECISION SUPPORT SYSTEM FOR FARM WATER MANAGEMENT IN SURFACE IRRIGATION: MODEL DEVELOPMENT AND APPLICATION
}

\author{
Carlos I. Flores ${ }^{1 *}$, Eduardo A. Holzapfel ${ }^{1}$, and Octavio Lagos ${ }^{1}$
}

\begin{abstract}
An online dynamic decision support system (DDSS) was developed, to support the farm water management in surface irrigation. The online DDSS was based on the formulation and integration of three components: a dynamic-relational data base, an administrator model, and a graphical user interface. The DDSS allows routines of actualization, edition and addition of online data, providing information in real time. The online DDSS was applied in an orange orchard (Citrus sinensis L. Osbeck) cv. Valencia Late under furrow irrigation. The results pointed out that the time irrigation cutoff was the main significant management factor, to decrease the hazard of leaching, superficial runoff and percolation. Applying the results obtained with the DDSS, furrow irrigation efficiencies could be improved up to values equals to $95.89 \%$ for application efficiency and $94.61 \%$ for total distribution efficiency. As a conclusion, the DDSS demonstrated to be a useful tool to assist the decision making process, providing proper information for the management of the available water resource at farm level.
\end{abstract}

Key words: furrow irrigation, on-line irrigation management, orange orchard.

\section{INTRODUCTION}

Applied technology to irrigation systems is the appropriate method to offer sustainability to agricultural production, considering the rational use of the available water as a central variable (Flores and Holzapfel, 2009). The optimum management of available surface and subsurface water resources, with respect to quantity and quality, is urgently needed in view of the increasing demands, limited resources and soil salinization (Flores et al., 2008). New technologies and improvement of on-farm water management are essential to solve these problems (Kumar and Singh, 2003). Then, one of the accessible technologies in the present, are the decision support systems (DSS), which can be understood as a technological tool to assist the decision making process for a specific purpose.

A DSS is an interactive computational system that involves the formulation and integration of three main components, a data base, an administrator model and a graphical user interface, and can incorporate the decision makers' own insights. A significant improve to the DSS,

${ }^{1}$ Universidad de Concepción, Facultad de Ingeniería Agrícola, Vicente Méndez 595, casilla 537, Chillán, Chile. *Corresponding authors (carlflores@udec.cl).

Received: 24 April 2009.

Accepted: 09 September 2009. is the dynamic decision support system (DDSS), which allows routines of actualization, edition and addition of data, providing as a result, accurate information in appropriated time, and assisting adequately the decision making process (Flores et al., 2008).

At the present, several DSS have been developed to assist the water management processes. Lilburne et al. (1998) developed a DSS which integrates the simulation model SWIM (developed by Wang et al., 1996), and a decision making tree to provide the most probable water requirements of a certain crop production. Da Silva et al. (2001) set up a DSS to provide assistance to the planning and management of farm irrigation at large scale, giving as results the specific policies and actions for each one of the agricultural producers included in the analysis, as well as their respective yields and production cost. Mateos et al. (2002) developed the DSS SIMIS (Scheme irrigation management information system) for managing irrigationschemes. SIMIS uses a coherent modeling approach based on the water balance, with two management modules (the first for water management and the second for financial management). The water management module in SIMIS deals with four key issues: crop water requirements, seasonal irrigation planning, water delivery scheduling, and recording water consumption, whereas the financial management deals with the incomes and costs viabilities. SIMIS also 
contain a geographic information system, giving the option to visualize geo-referenced information. Giupponi et al. (2004) developed a multi objective DSS called MULINO (Multi-sectorial, integrated and operational decision support system for the sustainable use of water resources at the catchment scale), with the main objective to assist the decision making process related to minimize the contamination of the aquifers and lagoons, product of disposals water. Janssen et al. (2003) made a DSS called EVALUWET (European valuation and assessment tool supporting wetland ecosystem legislation), to develop management policies for swamps areas. Lately, Rao et al. (2007) formulated a web-based GIS DSS for managing and planning USDA's Conservation Reserve Program. Other remarkable works are Gpfarm (Shaffer and Brodahl, 1998), Modsim DSS (Fredericks et al., 1998), Dsirr-multi-scale analysis of irrigation (Bazzani, 2005a), Dsirr-irrigation and water policy design (Bazzani, 2005b), Rwm-Crss (Rajasekaram and Nandalal, 2005), ENSObased irrigation decision support (Paz et al., 2007), IDSS-C (Giordano et al., 2007), all formulated as DSS to assist the water management.

Thus, the developments of DSS and DDSS as well its applications to assist the water management, have been an important area of both, constant investigations and integration of scientific knowledge, considering the environmental benefices of an accurate use of the available water (Flores et al., 2008).

The objectives of this study were: a) to develop an online DDSS; b) to apply the system in an orange orchard (Citrus sinensis L. Osbeck) cv. Valencia Late under furrow irrigation; c) to evaluate the actual irrigation management carried on in the orchard; d) to determinate both, the suitable water management factors and the irrigation efficiencies; and e) to improve the farm water management.

\section{MATERIALS AND METHODS}

\section{Model development}

The online DDSS was called INNOVA RIEGO, which is an integrated assembly of mathematical models, data, and interpretative procedures that efficiently processes the inputs, runs the models and gives the results in real time in an easy way for interpretation. INNOVA RIEGO involves an administrator model (AdM) with decision making capabilities, a relational database management system (RDBM) and a graphical user interface (GUI).

The AdM is an assembling of $\mathrm{C \#}$ and Matlab programming languages, whereas RDBM was structured as Structured Query Language (SQL). These both systems interact between each other with the GUI, which was developed as ASPX pages (Active Server Pages) including
HyperText Markup Language (HTML). Since INNOVA RIEGO is a web based system, needs a computer, Internet connection, and a web browser to deploy the GUI.

\section{Principles of operation for INNOVA RIEGO}

The principles of operation of INNOVA RIEGO are based upon three main levels of hardware and software, being the first one the SQL Server application client, whereas the second and third are the data base hardware, and the Internet server respectively. The Figure 1 deploys a diagram of the three main levels of the DDSS, whereas the Figure 2 illustrates the principles of operation of INNOVA RIEGO, settled as a flow diagram.

The inputs parameters are stored in the RDBM or submitted by the user, and then, are evaluated by the AdM to assure a properly range of the data. Subsequently, the user is guided to options of dynamic support for water management.

Afterward, the user can select between water requirement management and surface irrigation, to obtain support based on his actual needs. Once the results are deployed, INNOVA RIEGO submits the results to evaluation according to an Expert System criterion, which guide and assist the user to achieve the suitable solution, and finally take the proper decision.

\section{Inputs to apply INNOVA RIEGO}

The information needed to run INNOVA RIEGO, must be obtained previously by field tests or from literature. INNOVA RIEGO requires inputs related to both, water

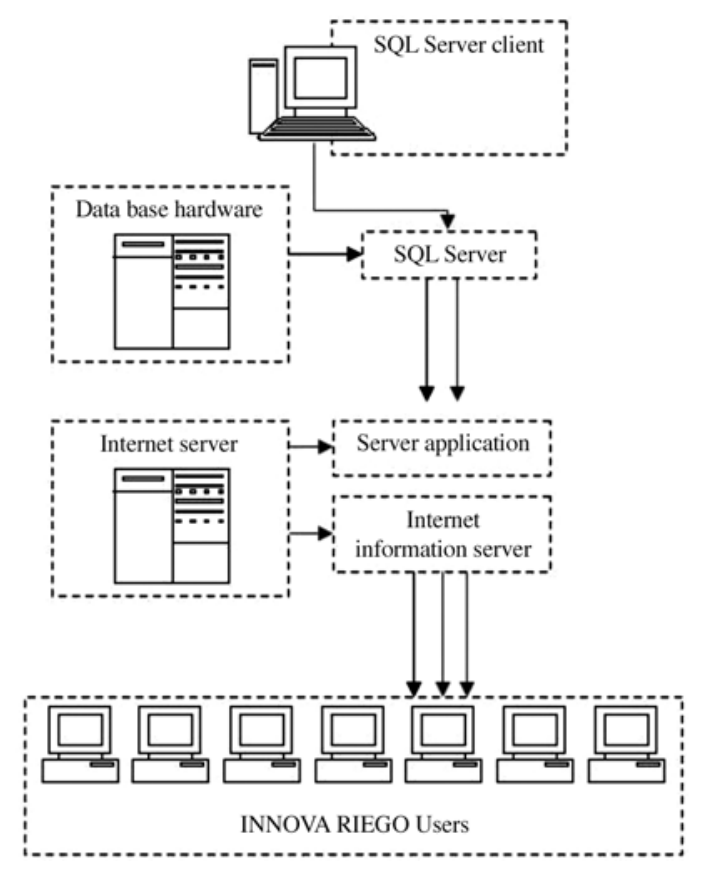

Figure 1. Principles of operation for INNOVA RIEGO. 


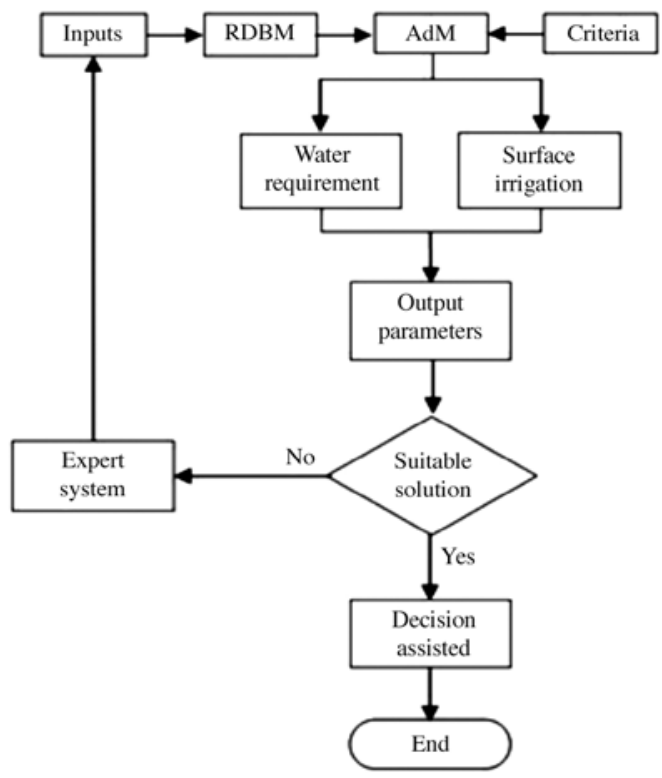

RDBM: Relational database management system. AdM: Administrator model.

Figure 2. Function schematization of INNOVA RIEGO as a flow diagram.

requirements and water managements parameters. Inputs for water requirements are: daily values of pan evaporation $\left(\mathrm{mm} \mathrm{d}^{-1}\right)$ and actual irrigation criteria applied by the user, at the moment of the study. Water management parameters are: the furrow discharge $\left(\mathrm{m}^{3} \mathrm{~min}^{-1}\right)$, the cut back discharge $\left(\mathrm{m}^{3} \mathrm{~min}^{-1}\right)$, simulation delta time (min), the time of cut off ( $\mathrm{min})$, the irrigation water requirements $\left(\mathrm{m}^{3} \cdot \mathrm{m}^{-1}\right)$ of the crop, the furrow slope $\left(\mathrm{m} \mathrm{m}^{-1}\right)$, distance between furrows $(\mathrm{m})$ and the length of the furrows $(\mathrm{m})$.

To utilize the online DDSS, each one of the users must be registered with a membership account, stored in the RDBM to access into the system. Once the user is already logged in, the system automatically identifies the characteristics of the production scenario that the user has in his farm. Thus, to apply INNOVA RIEGO in one particular production scenario, the user must submit his username, password and email address. Due to INNOVA RIEGO was developed to assist the Chilean's farm water management, all the graphical user interfaces are in Spanish language.

\section{INNOVA RIEGO water requirement module}

For surface irrigation, the water requirement module is based on the determination of both, the water requirements and irrigation frequency, over the basis of the user's actual conditions, which are automatically identified by the system at the moment of login into the platform.

Thus, to calculate the water requirements, INNOVA RIEGO applies the relationship proposed by Holzapfel et al. (2004):

$$
E T a=E B * K_{b} * F_{c}
$$

In which

$$
\begin{gathered}
F_{c}=K_{1} * P c+K_{2} \\
P_{c}=\frac{A_{s}}{H * L}
\end{gathered}
$$

where ETa is the actual evapotranspiration $\left(\mathrm{mm} \mathrm{d}^{-1}\right), E B$ the pan evaporation $\left(\mathrm{mm} \mathrm{d}^{-1}\right), K_{b}$ the pan coefficient, $P \mathrm{c}$ the percentage of canopy cover $(10 \leq P \mathrm{c} \leq 70), F_{\mathrm{c}}$ the crop/orchard factor with values between 0.2 and $1.0, K_{1}$ and $K_{2}$ are constants of canopy cover factor, $A_{\mathrm{s}}$ the canopy cover area at noon $\left(\mathrm{m}^{2}\right)$, given by the Equation [4], $H$ the distance between rows $(\mathrm{m})$, and $L$ the distance between plants within the row $(\mathrm{m})$.

$$
A_{s}=\frac{D_{c f}^{2} * \pi}{4}
$$

where $D_{c f}$ is the shadow canopy diameter at noon (m).

The $F_{\mathrm{c}}$ factor is a function of the agricultural practices, irrigation system used, type and size of orchard, plant density, and the climatic conditions of the area (Holzapfel et al., 2004). Under the conditions of this study, the values corresponding to $K_{1}$ and $K_{2}$ were 0.00768 and 0.1125 , respectively.

To determinate the irrigation frequency it is necessary to express the value of ETa in $\mathrm{m}^{3}$ per tree or crop, according to their influence area. Therefore, the output of ETa, expressed in volumetric units, is given by the following relation:

$$
\text { EtaVol }=\frac{0.001 * E T a * H * L}{E D T}
$$

where EtaVol is the water requirement per tree in $\mathrm{m}^{3}$ per tree or crop, and EDT is the total distribution efficiency of the system $(0 \leq E D T \leq 1)$, which one is given by the following expression:

$$
E D T=\left[1-\frac{\sum_{i=1}^{n}\left|x_{i}-x_{y}\right|}{n_{t} * x_{y}}\right]
$$

where $x_{i}$ is the infiltrated water in the point $i(\mathrm{~mm}), x_{y}$ the water requirement $(\mathrm{mm})$, and $n_{t}$ the total simulation nodes. As an endogenous calculus process, INNOVA RIEGO performs the properly unit conversions for $E D T$ determination.

The irrigation frequency is calculated by the next equation:

$$
I F=\frac{A_{s} * r_{d} * I R * S_{f}}{E t a V o l}
$$


where $I F$ is the irrigation frequency (d), $A_{s}$ already given in Equation [4] and defined in Equation [3], $r_{d}$ the root uptake depth $(\mathrm{m}), I R$ the irrigation criterion settled in 0.5 , and $S_{f}$ is an adjustment value $\left(\mathrm{m}^{3} \mathrm{~m}^{-3}\right)$ according to the soil characteristics, calculated according to the next expression:

$$
S_{f}=\frac{(F-W)}{100} * d a
$$

where $F$ and $W$ are the field capacity and wilting point of the soil respectively in percentage, and $d a$ correspond to the bulk density of the soil in $\mathrm{kg} \mathrm{m}^{-3}$.

Finally, for the water requirement of the orchard or crop under furrow irrigation, INNOVA RIEGO assumes that the reposition rate is a function of both, the water required in the soil profile where the root uptake zone is located and its soil characteristics, and the furrow properties.

Therefore, the water requirement is calculated according to the following equation:

$$
\operatorname{Re} q V=\frac{A_{s} * r_{d} * I R * S_{f}}{L * n_{s}}
$$

where $\operatorname{ReqV}$ is the water requirement per tree or crop $\left(\mathrm{m}^{3} \mathrm{~m}^{-1}\right)$, and $n_{s}$ the number of furrow per tree or crop. This output is the one that the surface irrigation module requires to run the model.

Thus, as output parameters, for the water requirement module, INNOVA RIEGO gives as a results the values of $R e q V$ and $I F$.

\section{INNOVA RIEGO surface irrigation module}

Inside the surface irrigation module, is the furrow irrigation system support GUI. The equations describing continuity of mass, momentum and energy that INNOVA RIEGO applies for the furrow irrigation module, are the Saint-Venant equations (Equation [10] and Equation [11]).

$$
\begin{aligned}
& \frac{S \partial V}{\partial x}+\frac{b V \partial y}{\partial x}+\frac{b \partial y}{\partial t}+D=0 \\
& \frac{\partial V}{g \partial t}+\frac{V \partial V}{g \partial x}+\frac{\partial y}{\partial x}=S_{0}-S_{y}+\frac{I V}{2 g S}
\end{aligned}
$$

where $S$ is the cross-sectional area of the flow, $b$ the top width of flow, $g$ the weight-to mass ratio, $D$ the infiltration, $x$ the distance, $y$ the depth of flow, $S_{0}$ the channel slope, $S_{y}$ the water slope, $V$ the velocity and $t$ the time.

INNOVA RIEGO uses the Volume Balance model, the geometry factors of the furrows, and the KostiakovLewis infiltration equation (Equation [12]), to estimate both the advance and recession phases across the furrow. For the geometry factors of the furrows, the equations involved are those described by Karmeli et al. (1978) and
Mostafazadeh-Fard (1982). INNOVA RIEGO facilitates to the users the determination of these factors, requiring only as an input parameters, the measurement of the furrow form and the water height at the furrow.

$$
D=A T^{B}+C T
$$

where $D$ as the volume of water infiltrated in $\mathrm{m}^{3} \mathrm{~m}^{-1}, T$ the time that water has been in contact with the soil ( $\mathrm{min})$, and $A\left(\mathrm{~m}^{3} \mathrm{~m}^{-1} \mathrm{~min}^{\mathrm{B}}\right)$, as well as $B$ and $C\left(\mathrm{~m}^{3} \mathrm{~m}^{-1} \mathrm{~min}^{-1}\right)$ are constants.

The Volume Balance approach neglects the momentum equation related to the temporal and spatial changes in velocity and depth as water flows over the irrigation field. INNOVA RIEGO applies this model using a numerical solution, which is an implicit method and thus, stable in their results (Flores et al., 2008). Thus, for the advance phase, INNOVA RIEGO calculates the Volume Balance model resolving the following equations, which ones are derived from Equation [10] and Equation [11]:

$$
\begin{gathered}
\frac{\partial Q}{\partial x}+\frac{\partial A_{r}}{\partial t}+D=0 \\
S_{0}=S_{y}
\end{gathered}
$$

where $\mathrm{Q}$ the discharge flow and $A_{r}$ the cross-sectional area of the flow. In relation to the recession phase, INNOVA RIEGO uses the solution proposed by Holzapfel (1984), to calculate the infiltration time of water remaining in the furrow after the time of cut off.

\section{Outputs of INNOVA RIEGO}

Through the entire simulation process, the online DDSS submits outputs parameters to evaluation, giving to the user recommendations to improve their water management. For example if INNOVA RIEGO evaluates the application efficiency under an acceptable value, the system will recommend to reduce the time of cutoff. The guiding process last until the irrigation efficiencies reach suitable values, being the stopping criteria those shown in Table 1, considering any value lower than "Good" as "Less than good". To improve the farm water management in surface irrigation, the user is guided to obtain a minimum of good state, with the chance to reach an excellent status.

Once the simulation had being done, INNOVA RIEGO provides as outputs parameters of irrigation analysis and irrigation efficiencies. The outputs of surface irrigation analysis are: volume of water applied $\left(\mathrm{m}^{3}\right)$, volume of water infiltrated $\left(\mathrm{m}^{3}\right)$, volume percolated $\left(\mathrm{m}^{3}\right)$, deep percolation percentage, runoff volume $\left(\mathrm{m}^{3}\right)$, and runoff percentage. Whereas for the irrigation efficiencies outputs, INNOVA RIEGO gives as a result the application 
Table 1. Range for management factor status.

\begin{tabular}{lccc}
\hline & \multicolumn{3}{c}{ Management factors atatus } \\
\hline & EAP $<60$ & $\%$ & EDT $<60$ \\
Less than good & $60 \leq$ EAP $<70$ & ER $<70$ & $60 \leq$ EDT $<70$ \\
Good & $70 \leq$ EAP $<80$ & $70 \leq$ ER $<75$ & $70 \leq$ EDT $<80$ \\
Very good & $80 \leq$ EAP & $75 \leq$ ER $<80$ & $80 \leq$ EDT \\
Excellent & $80 \leq$ ER & \\
\hline
\end{tabular}

EAP: application efficiency; ER: water requirement efficiency; EDT: total distribution efficiency.

EAP, ER and EDT in \%.

efficiency EAP (\%), requirement efficiency ER (\%) and total distribution efficiency EDT (\%).

\section{Application INNOVA RIEGO}

Characteristics of the area in study. INNOVA RIEGO was applied to an orange (Citrus sinensis L. Osbeck) orchard field located at Peumo Valley $\left(34^{\circ} 17^{\prime} \mathrm{S}, 71^{\circ} 19^{\prime}\right.$ W), Las Cabras district, Libertador General Bernardo O'Higgins Region, Chile. The Mediterranean weather is predominant in the area, having variations due to the effect of the local topography. The hydrographic system is constituted by the Cachapoal River, which in its confluence with the Tinguiririca River, give rise to the Rapel Lake, in a point called La Junta. The orange orchard cv. Valencia Late has $5 \mathrm{~m}$ between rows and $4 \mathrm{~m}$ over the rows, being $D_{c f}$ equals to $3.7 \mathrm{~m}$, and yielding $60000 \mathrm{~kg} \mathrm{ha}^{-1} \mathrm{yr}^{-1}$.

Two furrows per row are located at $0.5 \mathrm{~m}$ distant from the trunk, having $120 \mathrm{~m}$ length and $1 \mathrm{~m}$ between them.

The application of INNOVA RIEGO was based on the simulation of the 2007-2008 irrigation season, and at the moment of the study, the user had the property information needed to run INNOVA RIEGO. Therefore, the Table 2 shows the values related to the furrows forms necessaries to obtain the geometry factors. Table 3 shows the historical month mean values of $E B$, corresponding to the measures realized by the user since the year 2000 until April 2007.

With these parameters, the user was able to simulate both, the suitable water management and surface irrigation

Table 2. User's furrow form data.

\begin{tabular}{lc}
\hline $\begin{array}{l}\text { X furrow axis } \\
\text { distance }\end{array}$ & $\begin{array}{c}\text { Y furrow axis } \\
\text { height }\end{array}$ \\
\hline & \\
\hline 0.00 & $\mathrm{~m}$ \\
0.05 & 0.150 \\
0.10 & 0.137 \\
0.15 & 0.100 \\
\hline
\end{tabular}

Table 3. User's historical pan evaporation means.

\begin{tabular}{lc}
\hline Month & Pan evaporation \\
\hline & $\mathrm{mm} \mathrm{d}^{-1}$ \\
October & 3.93 \\
November & 6.41 \\
December & 7.31 \\
January & 7.35 \\
February & 7.01 \\
March & 6.29 \\
April & 2.77 \\
\hline
\end{tabular}

efficiencies of his production system, as well as the water requirement of the orange orchard field during the 20072008 irrigation season.

\section{RESULTS AND DISCUSSION}

Water requirement calculation is the first process in INNOVA RIEGO to start the dynamic decision support with a relatively similar approach as Lilburne et al. (1998) and Mateos et al. (2002). According to the water requirements module, the water reposition rate should be refilling the root uptake zone in each irrigation, as a function of both, the water requirement $(\operatorname{Req} V)$ and the irrigation frequency (IF). Thus, the result of $R e q V$ was $0.069 \mathrm{~m}^{3} \mathrm{~m}^{-1}$, and the $I F$ results were those shown in the Table 4. As an example, the Figure 3 illustrates the GUI of INNOVA RIEGO to obtain the water requirement and irrigation frequency for January 2008.

Afterwards, with the water requirements already calculated for the 2007-2008 irrigation season, it was possible to apply the surface irrigation module. Holzapfel et al.(1986) used an optimization model to give the optimal value of design variable only for a critical condition, in contrast INNOVA RIEGO solve online the irrigation variables for each irrigation event, giving flexibility to the agricultural activity and proper information for the management of the available water resources. 
Table 4. Water requirement simulation results, 2007-2008 irrigation season.

\begin{tabular}{lc}
\hline Month & Irrigation frequency \\
\hline & $\mathrm{d}$ \\
October 2007 & 13 \\
November 2007 & 8 \\
December 2007 & 7 \\
January 2008 & 7 \\
February 2008 & 7 \\
March 2008 & 8 \\
April 2008 & 19
\end{tabular}

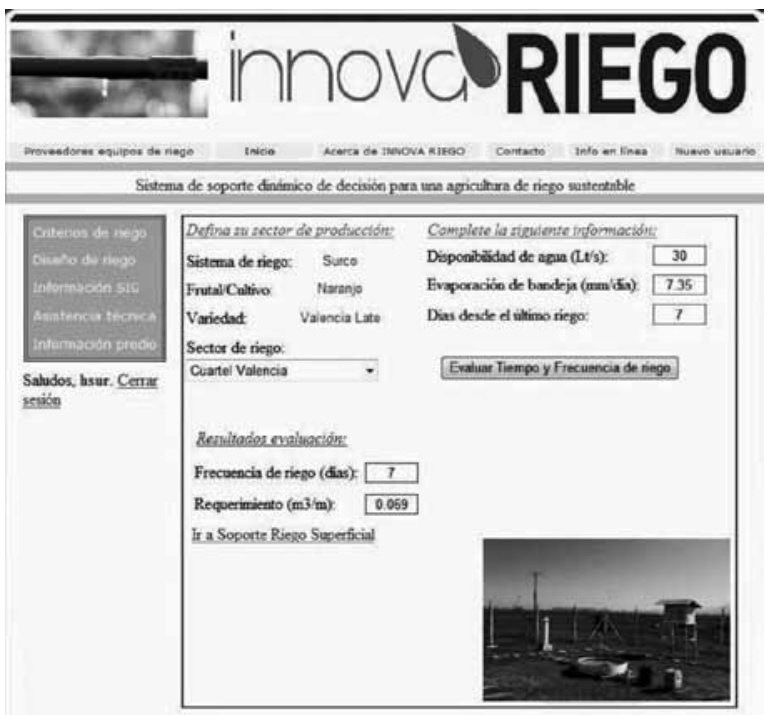

Figure 3. INNOVA RIEGO water requirement graphical user interface for January 2008.

Thus, by clicking in the link "Ir a Soporte Riego Superficial" (Go to the surface irrigation support), the online DDSS deploy the GUI to calculate the geometry factors of the furrow (Figure 4).

With the furrow forms factors calculated, the user is carried on to the Volume Balance model graphical interface. Here the input data required to run the model are: parameters of Kostiakov-Lewis infiltration equation, being $\mathrm{A}, \mathrm{C}, \mathrm{y} \mathrm{B}$ equals to $0.009 \mathrm{~m}^{3} \mathrm{~m}^{-1} \mathrm{~min}^{0.5}, 0.0$, and 0.5 , respectively, the roughness manning coefficient, used as default a value of 0.025 , geometry factors obtained previously, the furrow discharge equal to $0.2 \mathrm{~m}^{3} \mathrm{~min}^{-1}$ and the cut back discharge of $0.1 \mathrm{~m}^{3} \mathrm{~min}^{-1}$. Furrow characteristics were: $0.008 \mathrm{~m} \mathrm{~m}^{-1}$ for the furrow slope, 1 $\mathrm{m}$ of distance between furrows, $120 \mathrm{~m}$ for the length of the furrows and $120 \mathrm{~min}$ as time of cut off.

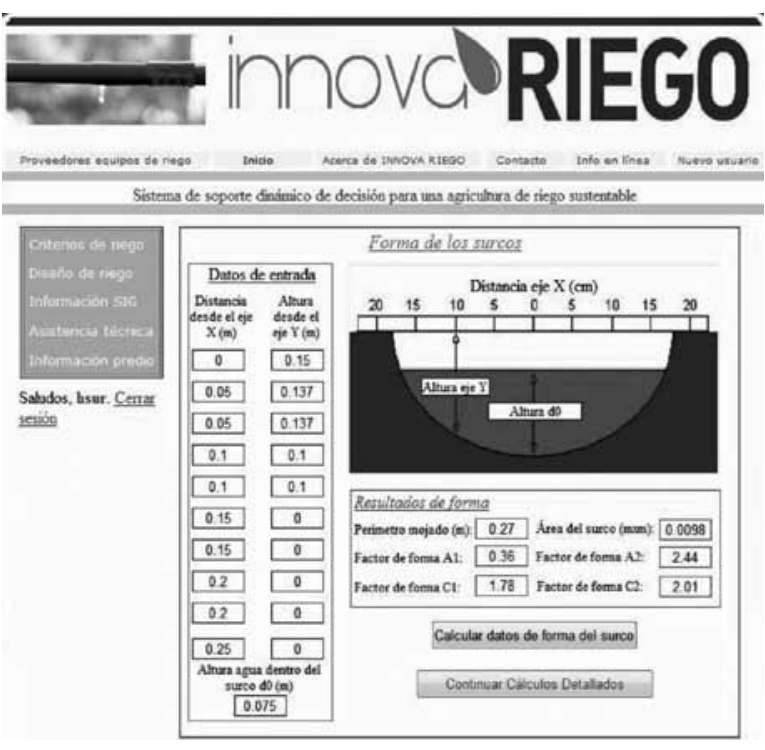

Figure 4. INNOVA RIEGO furrow geometry factors graphical user interface.

These values were the actual conditions of the user, and were submitted to analysis to evaluate its performance. The Figure 5 shows the application of the Volume Balance model and the results obtained for these initial conditions, which were further modified to obtain suitable management values.

With the actual conditions of the user and due to the larger amounts of percolation and runoff, the irrigation

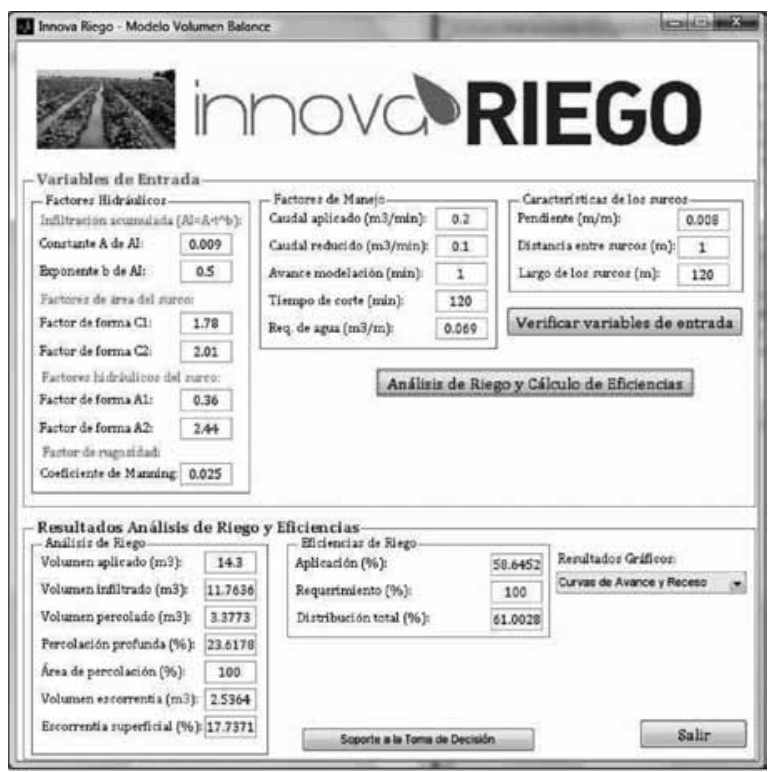

Figure 5. INNOVA RIEGO volume balance graphical user interface for the user initial conditions. 
efficiencies were $61.0 \%$ for total distribution efficiency and $58.65 \%$ for application efficiency, achieving a management factor status equals to "Less than good" (Figure 5). Then, the user was able to improve his irrigation water management and efficiencies guided by INNOVA RIEGO.

As a result, the variables submitted to support, were the furrow discharge, cut back discharge, time of cut off, and furrow length, which are considered by INNOVA RIEGO as the furrow decision variables. Therefore, INNOVA RIEGO led the user to obtain the proper values for these inputs and in consequence, improve the water management of his farm system.

Hence, the INNOVA RIEGO's guiding process recommended the modification of the following inputs parameters: furrow length, furrow discharge, cut back discharge and time of cut off, being these ones equals to $0.15 \mathrm{~m}^{3} \mathrm{~min}^{-1}, 0.08 \mathrm{~m}^{3} \mathrm{~min}^{-1}, 70 \mathrm{~min}$ and $110 \mathrm{~m}$, respectively. Consequently, applying the recommended data, the user achieve a management factor status of "Excellent", due to the results of application efficiency, requirement efficiency and total distribution efficiency were $95.89 \%, 98.43 \%$ and $94.61 \%$ respectively. The Table 5 shows the results of both, the initial condition of the user and the improved scenario, as a result of the INNOVA RIEGO's guiding process.

Additionally, in the menu "Resultados Gráficos" (Graphical results), the user is capable to visualize the advance and recession curves, as well as the infiltration curve and a pie diagram of the percentages of volume flow infiltrated, volume percolated and runoff volume. The Figure 6 illustrates the advance and recession curves obtained for the improved results across the furrow length, whereas the Figure 7 shows the infiltration curve, where over the $75 \mathrm{~m}$ of furrow length was developed some water deficit, explaining the requirement efficiency obtained previously $(98.43 \%)$.

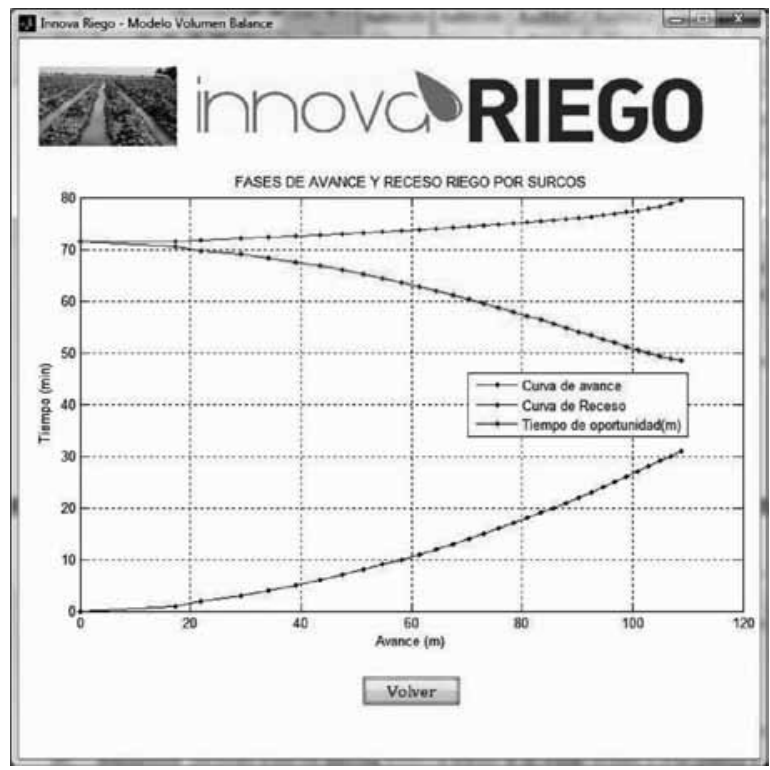

Figure 6. INNOVA RIEGO volume balance graphical user interface for the advance and recession curves across the furrow.

Table 5. INNOVA RIEGO furrow irrigation results.

\begin{tabular}{lcc}
\hline Results & Initial condition & Improve scenario \\
\hline Furrow length, $\mathrm{m}$ & 120.00 & 110.00 \\
Furrow discharge, $\mathrm{m}^{3} \mathrm{~min}^{-1}$ & 0.20 & 0.15 \\
Cut back discharge, $\mathrm{m}^{3} \mathrm{~min}^{-1}$ & 0.10 & 0.08 \\
Time of cut off, min & 120.00 & 70.00 \\
Furrow applied volume, $\mathrm{m}^{3}$ & 14.30 & 7.84 \\
Furrow infiltrated volume, $\mathrm{m}^{3}$ & 11.76 & 7.86 \\
Furrow percolated volume, $\mathrm{m}^{3}$ & 3.37 & 0.34 \\
Furrow runoff volume, $\mathrm{m}^{3}$ & 2.54 & 0.00 \\
Deep percolation, \% & 23.62 & 4.39 \\
Percolated area, \% & 100.00 & 100.00 \\
Superficial runoff, $\%$ & 17.74 & 0.00 \\
Application efficiency, $\%$ & 58.65 & 95.89 \\
Requirement efficiency, $\%$ & 100.00 & 98.43 \\
Total distribution efficiency, \% & 61.00 & 94.61 \\
Management factor status & Less than good & Excellent \\
\hline
\end{tabular}




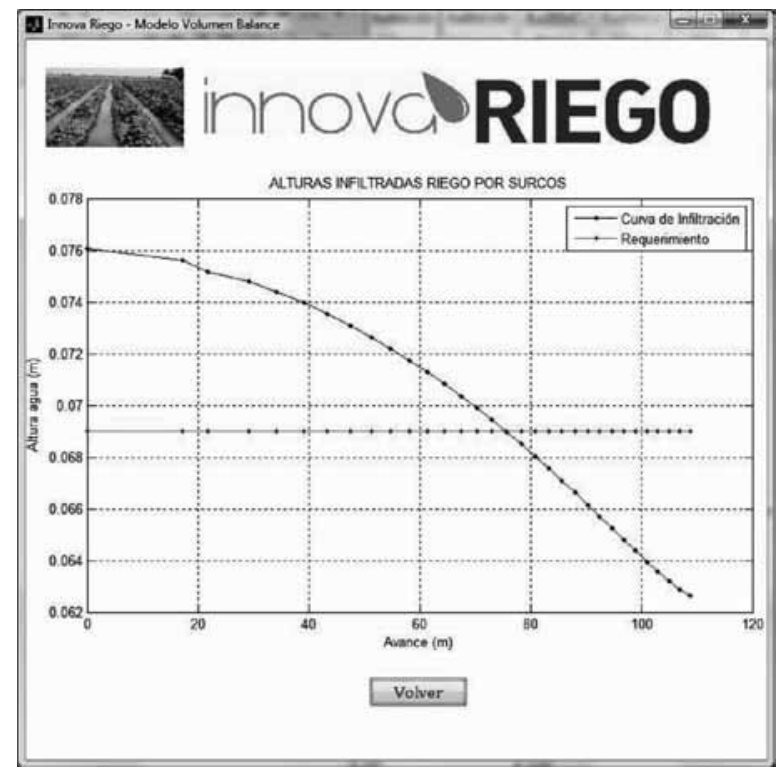

Figure 7. INNOVA RIEGO volume balance graphical user interface for the infiltration curve across the furrow.

\section{CONCLUSIONS}

An online dynamic decision support system was developed to assist farm water management in surface irrigation. The online DDSS was based on the formulation and integration of three main components, a dynamic-relational data base, an administrator model and a graphical user interface. The DDSS allows routines of actualization, edition and addition of online data. Additionally, the system provides to decision makers information in real time to support both, irrigation systems designs and suitable water management criteria.

The online dynamic decision support system INNOVA RIEGO was applied in an orange orchard cv. Valencia Late, under furrow irrigation to evaluate the actual irrigation management carried on in the orchard, and determinate both, the suitable water management factors and the respectively irrigation efficiencies of the production system.

The evaluation of the actual water management criteria normally applied by the user, reached lows values of both, application and total distribution efficiencies, $58.65 \%$ and $61.0 \%$, respectively, settling as a result a management factor status equals to "Less than good". Using INNOVA RIEGO, these values were improved up to values of $95.89 \%$ for application efficiency and $94.61 \%$ for total distribution efficiency, accomplishing an "Excellent" management factors status, taking the furrow discharge, cut back discharge, cut of time and furrow length as decision support variables. The results achieved, exposed that the user was able to improve his farm water management, reaching sustainable results, reducing significantly the quantities of percolation and surface runoff, and increasing the irrigation efficiencies.

In consequence, INNOVA RIEGO is a computational tool that can assists adequately the decision making process, improving the efficiency of water management, supporting the sustainability of the farm, and give flexibility to the agricultural activity as well as proper information for the management of the available water resource.

\section{ACKNOWLEDGEMENTS}

The research reported in this paper was conducted at the Department of Water Resources of Universidad de Concepción, at Chillán, Chile, as part of the FONDEF D02I-1146 and the INNOVA-BIOBIO 07-EMS 2.1-207 projects.

\section{RESUMEN}

Un sistema de soporte dinámico de decisión para la gestión de agua predial en riego superficial: Desarrollo y aplicación del modelo. Se desarrolló un sistema de soporte dinámico de decisión (SSDD) en línea, con el objetivo de asistir la gestión del agua predial en riego superficial. El SSDD en línea se basó en la formulación e integración de tres componentes: una base de datos relacional dinámica, un modelo administrador y una interfaz gráfica de usuario. El SSDD permite rutinas de actualización, edición y adición de información en línea, proporcionando información en tiempo real. El SSDD en línea se aplicó en un huerto de naranjos (Citrus sinensis L. Osbeck) cv. Valencia Late bajo riego por surcos. Los resultados indicaron que el tiempo de corte es la variable significativa de decisión para disminuir el riesgo de lixiviación, escorrentía superficial y percolación. Aplicando los resultados obtenidos con el SSDD, las eficiencias del riego por surco podrían mejorarse, alcanzando valores iguales a $95,89 \%$ de eficiencia de aplicación y $94,61 \%$ de eficiencia de distribución total. En conclusión, el SSDD demostró ser una herramienta útil para asistir el proceso de toma de decisiones, proporcionando información adecuada para la gestión del agua disponible a nivel predial.

Palabras clave: riego por surco, manejo de riego en línea, huerto de naranjo.

\section{LITERATURE CITED}

Bazzani, G. 2005a. A decision support for an integrated multi-scale analysis of irrigation: DSIRR. Environ. Manage. 77:301-314. 
Bazzani, G. 2005b. An integrated decision support system for irrigation and water policy design: DSIRR. Environ. Modell. Softw. 20:153-163.

Da Silva, M., J.R. Park, J. Keatinge, and P. Pinto. 2001. II. The use of the DSSIPM in the Alentejo region of southern Portugal. Agr. Water Manage. 51:203-215.

Flores, C., and E. Holzapfel. 2009. Dynamic decision system support to assist the suitable water management of an orchard under furrow irrigation. p. 100. The International Conference Science and Information Technologies for Sustainable Management of Aquatic Ecosystems, $8^{\text {th }}$ International Conference on Hydroinformatics, Concepción, Chile. 12-16 January 2009. Universidad de Concepción, Concepción, Chile.

Flores, C., E. Holzapfel, y D. Rivera. 2008. Innova riego: Un sistema de soporte dinámico de decisión para la gestión integral de riego sustentable. p. 102. XI Congreso Ingeniería Agrícola y Áreas Afines, Medellín, Colombia. 9-11 de octubre de 2008. Universidad Nacional de Colombia, Medellín, Colombia.

Fredericks, J., J. Labadie, and J. Altenhofen. 1998. Decision support system for conjunctive streamaquiefer management. J. Water Res. Pl.-ASCE 124:69-78.

Giordano, R., G. Passarella, V. Uricchio, and M. Vurro. 2007. Integrating conflict analysis and consensus reaching in a decision support system for water resource management. Environ. Manage. 84:213-228.

Giupponi, C., J. Mysiak, A. Fassio, and V. Cogan. 2004. MULINO-DSS: a computer tool for sustainable use of water resources at the catchment scale. Math. Comput. Simulat. 64:13-24.

Holzapfel, E. 1984. Selection and design of surface irrigation methods. Ph.D. Thesis. University of California, Davis, California, USA.

Holzapfel, E., J. Jara, C. Zuñiga, M. Mariño, J. Paredes, and M. Billib. 2004. Infiltration parameters for furrow irrigation. Agr. Water Manage. 68:19-32.

Holzapfel, E., M. Mariño, and J. Chávez-Morales. 1986. Surface irrigation optimization model. J. Irrig. Drain. E-ASCE 112:1-19.
Janssen, R., M. Verhoeven, J. Verhoeven, A. Omtzigit, and E. Maltby. 2003. Decision support for integrated wetland management. Environ. Modell. Softw. 20:215-229.

Karmeli, D., L. Salazar, and W. Walker. 1978. Assessing the spatial variability of irrigation water applications. Document $N^{\circ}$ EPA-600/2-78-041. U.S. Environmental Protection Agency, Ada, Oklahoma, USA.

Kumar,R., and J.Singh. 2003. Regional water management modeling for decision support in irrigated agriculture. J. Irrig. Drain. E- ASCE 129:432-439.

Lilburne, L., J. Watt, and K. Vincent. 1998. A prototype DSS to evaluate irrigation management plans. Comput. Electron. Agr. 21:195-205.

Mateos, L., I. López-Cortijo, and J. Sagardoy. 2002. SIMIS: The FAO decision support system for irrigation scheme management. Agr. Water Manage. 56:193-206.

Mostafazadeh-Fard, B. 1982. Furrow geometry and roughness under surge and continuous flow. M.Sc. Thesis. Utah State University, Logan, Utah, USA.

Paz, J., C. Fraisse, L. Hatch, A. Garcia y Garcia, L. Guerra, et al. 2007. Development of an ENSO-based irrigation decision support tool for peanut production in the southeastern US. Comput. Electron. Agr. 55:28-35.

Rajasekaram, V., and K. Nandalal. 2005. Decision support system for reservoir water management conflict resolution. Water Res. Pl.-ASCE 131:410-419.

Rao, M., G. Fan, J. Thomas, G. Cherian, V. Chudiwale, and M. Awawdeh. 2007. A web-based GIS Decision Support System for managing and planning USDA's Conservation Reserve Program (CRP). Environ. Modell. Softw. 22:1270-1280.

Shaffer, M., and M. Brodahl. 1998. Rule-based management for simulation in agricultural decision support systems. Comput. Electron. Agr. 21:135-152.

Wang, F., A. Richardson, and F. Roddick. 1996. SWIM: A computer model for solid waste integrated management. Comput. Environ. Urban Syst. 20:233246. 